\title{
Genetic factors contributing to development of neonatal jaundice
}

\section{Jaundice}

Icterus, neonatal jaundice has long been recognized. In early $19^{\text {th }}$ century, the term Kernicterus was introduced, referring to the yellow colour development of basal ganglia in neonates, who died of jaundice. Due to high incidence of Kernicterus and Rh haemolytic diseases scientists focus on treatment of jaundice. ${ }^{1}$

\section{Neonatal jaundice}

In neonates pale colour of stools and urine are appearance of liver disease that should be investigated urgently. ${ }^{2}$ Neonatal jaundice is a common heterogeneous condition that usually resolves after 2 weeks of birth known as jaundice or icterus. ${ }^{3}$ If it is icterus of conjugated type, than it will last beyond two weeks time. When total serum bilirubin is less than $5 \mathrm{mg} / \mathrm{dL}$ and conjugated serum bilirubin is higher than $1 \mathrm{mg} / \mathrm{dL}$ than it is considered abnormal. Mutations in the regulatory region and exon of the gene encoding UDP-glucuronosyltransferase 1A1 (UGT1A1) enzyme leads to $30-70 \%$ decrease in the activity of enzyme. Enzyme is responsible for conjugation of bilirubin, and mutations in its gene are responsible for structural and functional defects. ${ }^{3}$ Previous studies showed that in patients showing iatrogenic factors such as glucose-6-phosphate dehydrogenase deficiency, hereditary spherocytosis, thalassemia or $\mathrm{ABO}$ incompatibility have homozygous polymorphism in the promoter region and homozygous or heterozygous mutations in exon1 of the UGT1A1 gene in Asians. ${ }^{5-7}$

\section{Hereditary predominantly unconjugated hyperbilirubinemia}

Inside endoplasmic reticulum bilirubin conjugation is catalysed by UGTIAl enzyme. When mutations in the gene occur, it leads to disruption in the expression of the gene, which in turn lead to complete or partial inactivation of enzyme. Phenobarbital (PB) administration increases the expression of UGT1A1 gene. PB response activity is delineated to a 290-bp distal enhancer module sequence (-3483/3194) glucuronosyltransferase phenobarbital response enhancing motif (gtPBREM) of the human UGT1A1. Human constitutive active receptor (hCAR), a nuclear orphan receptor is involved in activation of (gtPBREM). PB treatment results into translocation of cytoplasmic receptors like $\mathrm{CAR}$ into the nucleus; it binds to retinoid $\mathrm{X}$ receptor and forms a heterodimer, which leads to activation of $\mathrm{PB}$ response enhancer element. ${ }^{8}$ UGTIAl activity at different levels is found in three different types of inherited predominantly unconjugated bilirubinemia namely Criglar-Najjar syndrome type I (CN I), type II and Gilbert syndrome.

\section{Hereditary predominantly conjugated hyperbilirubinemia}

Bilirubin chemically bound to a glucuronide in the liver, which is excreted in bile by the liver and stored in the gallbladder or transferred to the duodenum. Dubin Johnson and Rotor syndrome are the two known types of hereditary conjugated jaundice. Patients suffering from both diseases are characterized by the presence of $>50 \%$ bilirubin in conjugated form. ${ }^{9}$
Volume 2 Issue 2 - 2017

\author{
Tabassum Rehan,' Muhammad Naeem,' \\ Nadira Jadoon, ${ }^{2}$ Touseef Rehan ${ }^{3}$ \\ 'Department of Biotechnology, Quaid-i-Azam University, \\ Pakistan \\ ${ }^{2}$ Department of Heamatology, National Institute of Health, \\ Pakistan \\ ${ }^{3}$ Department of Biochemistry and Molecular Biology, Quaid-i- \\ Azam University, Pakistan
}

Correspondence: Tabassum Rehan, Department of Biotechnology, Quaid-i-Azam University, Islamabad, Pakistan, Email tabassumrehan8@gmail.com

Received: August 25, 2017| Published: November 14, 2017

\section{Acknowledgements}

None.

\section{Conflict of Interest}

The author declares no conflict of interest.

\section{References}

1. Hyllis P, Ennery D, Aniels D, et al. Neonatal hyperbilirubinemia. Engl J Med. 2001;344(8):581-590.

2. McKiernan P. Neonatal jaundice. Clin Res Hepatol Gastroenterol. 2012;36(3):253-256

3. American Academy of Pediatrics Subcommittee on Hyperbilirubinemia. Management of hyperbilirubinemia in the newborn infant 35 or more weeks of gestation. Pediatrics. 2004;114(1):297-316.

4. Raijmakers MT, Jansen PL, Steegers EA, et al. Association of human liver bilirubin UDP glucuronyltransferase activity with a polymorphism in the promoter region of the UGT1A1 gene. J Hepatol. 2000;33(3):348351

5. Maruo $\mathrm{Y}$, Nishizawa $\mathrm{K}$, Sato $\mathrm{H}$, et al. Association of neonatal hyperbilirubinemia with bilirubin UDP-glucoronosyltransferase polymorphism. Pediatrics. 1999;103(6 Pt 1):1224-1227.

6. Kaplan M, Hammerman C, Renbaum P, et al. Gilbert syndrome and hyperbilirubinemiain $\mathrm{ABO}$-incompatible neonates. Lancet. 2000;356(9230):652-653.

7. Huang MJ, Kua KE, Teng $\mathrm{HC}$, et al. Risk factors for severe hyperbilirubinemia in neonates. Pediatr Res. 2004;56(5):682-689.

8. Eva S, Milan J. New insights in bilirubin metabolism and their clinical implications. World J Gastroenterol. 2013;19(38):6398-6407.

9. Elísio C, Emília V, Marcia M, et al. Analysis of the UDPglucuronosyltransferase gene in Portuguese patients with a clinical diagnosis of Gilbert and Crigler-Najjar syndromes. Blood Cell Mol Dis. 2006;36(1):91-97. 